\title{
Development Polarisation in Limbe and Kribi (Littoral Cameroon): Growth Challenges, Lessons from Douala and Options
}

\author{
Ojuku Tiafack ${ }^{1}$, Ngouanet Chrétien ${ }^{2}$, Ngwa Nebasina Emmanuel1 \\ ${ }^{1}$ Geography Department, University of Yaounde 1, Yaounde, Cameroon \\ ${ }^{2}$ Geography Department, University of Dschang, Yaounde, Cameroon \\ Email: tiafackojuku@yahoo.co.uk, chngouanet@yahoo.fr, Nebasina4@yahoo.co.uk
}

Received 17 October 2014; revised 17 November 2014; accepted 14 December 2014

Copyright (C) 2014 by authors and Scientific Research Publishing Inc.

This work is licensed under the Creative Commons Attribution International License (CC BY). http://creativecommons.org/licenses/by/4.0/

(c) (i) Open Access

\section{Abstract}

Limbe and Kribi respectfully in the Southwest and South Regions of Cameroon have been at the centre of Cameroon's industrial development since the beginning of the $21^{\text {st }}$ Century. These cities are being called upon to play important economic roles through heavy capital investments in the creation of deep sea ports, fishing, mining and energy production industries, the Chad-Cameroon pipeline terminus in Kribi, the cement factory and the petroleum refinery in Limbe amongst others. These developments are attracting and will continue to pull huge population numbers in these cities for jobs leading to urban growth. It is feared that if appropriate measures are not put in place, these emerging industrial towns located along the coastline of Cameroon will face problems of urban growth that are typical of Douala-the pioneer industrial capital of Cameroon and major nerve centre of the Central African sub Region. The growth challenges that Kribi and Limbe will face as well as lessons to learn from the experiences of Douala constitute the first focal point of this paper. These challenges are enormous and include pollution, crime and urban disorder resulting from uncoordinated transport, haphazard construction of habitats and risk vulnerability that threatens the sustainability of these cities. Decision makers in several Sub Saharan African countries are eager to develop their cities but do fail at the onset to project emerging problems that could stiffen this development process in the long run. Consequently, high cost intervention to combat urban disorder becomes the last option and therapy, when it is too late. The diverse measures put in place to redress the problems created are not only costly to the stakeholders (government, benevolent NGOs and the victims) but are indicators of development failures. This of recent has been typical of Yaounde and Douala, the political and economic capitals, respectively, of the Republic of Cameroon. The second important focal point of this paper examines the possible 
adverse effects of development polarisation in Limbe and Kribi and how the Douala scenario can be averted.

\title{
Keywords
}

\author{
Limbe, Kribi, Douala, Challenges, Lessons, Options, Industries, Urban Growth
}

\section{Introduction}

\subsection{Governments' Urbanisation Policy and Planning}

Today it is estimated that more than 50.4 percent of Cameroon's population live and work in urban areas. This population explosion, coupled with mounting shortage in financial resources, in the last two decades has revealed a fragile structural weakness for financing urban development. The slow recovery periods of 2000 with an annual economic growth of more than 3 percent and foreign debt cancellations led to a re-launched development projects. With the support of the World Bank, African development Bank and other foreign partners, the Cameroon government engaged in elaborating an alternative strategy of urban development, integrating emergent concepts such as: 1) environmental protection; 2) globalisation with regards to the fight against poverty, unemployment and crime amongst others; 3) sustainable development and of recent; 4) climate change. This development policy which saw the light in November 1999 have had as its main objective to improve on the livelihoods of the population and economic empowerment of the urban centres. This objective much more specifically targets the: 1 ) provision of basic needs of urban life with regards to housing, potable water, electrification, minimal drainage and garbage collection; 2) creation and maintenance of existing equipment and infrastructure; 3) definition of the roles of urban development actors with the view of efficient mobilization and valorisation of the interventions of local decentralised collectivities; and 4) coordination of urban planning and identification of priorities with a view of reinforcing the economic role and sustainability of urban centres.

In order to achieve these objectives the government of Cameroon has aligned its plan of action on many areas. These include promotion of private initiative in land tenure and construction of houses; definition of the institutional and legal framework of development of towns; promotion of job creation in urban and semi-urban areas; encouragement of partnership between the state, the urban councils and civil society; taxation of enterprises; and encouragement of citizens efforts towards town development.

Unfortunately, these actions have had little success in many Cameroon urban settings as typical of Douala the pioneer economic capital of Cameroon. Government has been obliged to use high cost measures to crack down urban disorder perpetrated by urban dwellers who either as a result of poverty have occupied marginal lands and risk zones or as a result of embezzlement of public funds, corruption, and favouritism have illegally occupied state lands reserved for development. Others have taken hostage of state property (houses) making it hard for the state and city councils to achieve the set objectives. There are fears these crises may affect Limbe and Kribi the emerging economic towns of Cameroon.

\subsection{Geographic Location}

Limbe is situated at the foot of Mount Cameroon and opens the South West Region to the rest of the World through the Atlantic Ocean. It was formerly known as Victoria and through the presidential decree of 1980, was renamed Limbe. Limbe is a sub-division and capital of Fako Division within which is located Buea-the regional capital of South West Region. Limbe made up of Limbe 1, 2 and 3 rivals Kumba as the economic capital of the South West Region. It has a surface area of $185 \mathrm{~km}^{2}$ and opens out from Man O War Bay across to Ambas Bay to the West, then to the Gulf of Guinea (Figure 1).

Kribi on the other hand is a secondary town located along the coastline of Cameroon between latitudes $2^{\circ} 56^{\prime}$ and $3^{\circ} 03^{\prime}$ North and longitudes $9^{\circ} 54^{\prime}$ and $9^{\circ} 57^{\prime}$ East (Figure 2). It is the headquarters of Ocean Division in the South Region of Cameroon. Ocean Division is made up of kribi I and II, Akom Bipindi, Campo, Lolordorf, Mvengue, Lokoundje Sub divisions and Nyiete District.

Both Kribi and Limbe are coastal secondary ports located along the Gulf of Guinea and adjacent to the Atlan- 


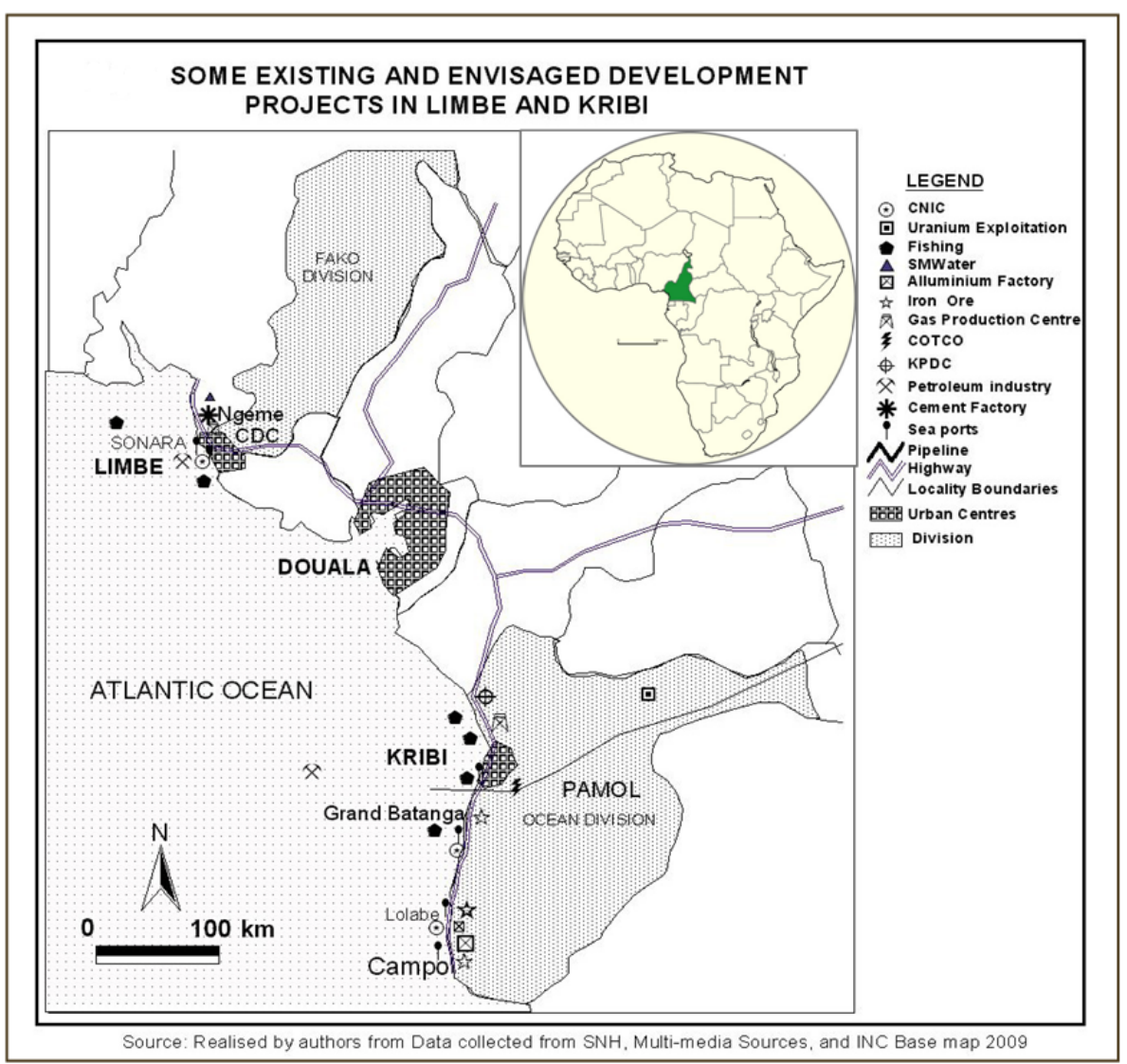

Figure 1. Location map and existing projects in Kribi and Limbe.

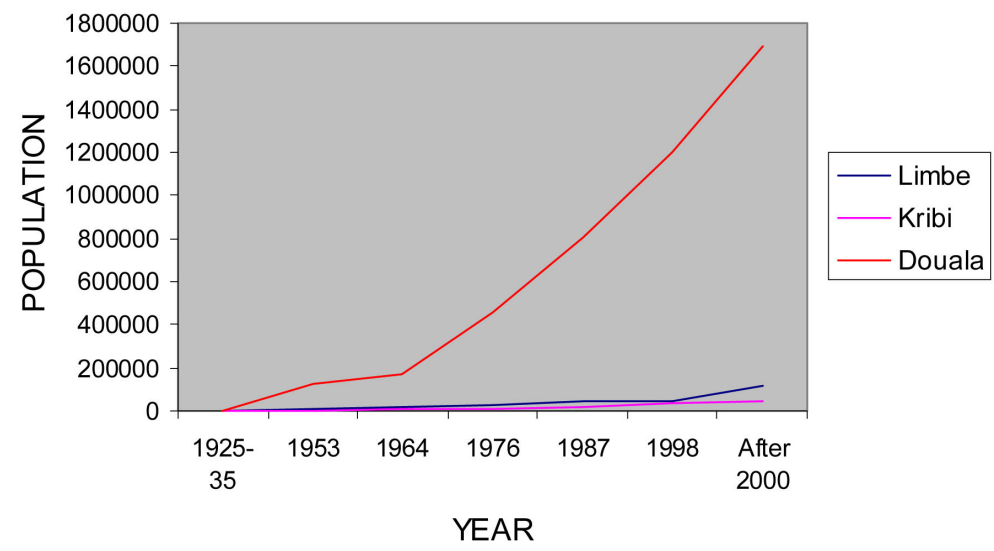

Figure 2. Population evolution of Limbe, Kribi and Douala. Source: J. Garet (1967), Motor colombus (1985), Schéma Directeur d’Aménagement de la Ville de Kribi, National Census on Population and Housing (1976, 1987), MINPAT (2000), BUCREP (2005), Projected data (2012).

tic Ocean (Figure 1). They are endowed with a rich climate that is good for Tourism, fishing, agriculture and small scale livestock breeding. This explains why both towns are adjacent to large capitalist plantations (CDC, Pamol-Limbe, SOCAPALM and Hevecam-Kribi) that are the largest employers (13,425 workers with 8600 living in Limbe) in Cameroon after the public service. Both towns have experienced European imperialism since creation. Today, they are being called upon by the Cameroon government and foreign partners to play metropolitan economic roles that will likely compete with their traditional tourism functions (Cameroon Tribune, 2009). 
The strategic positions of these towns offer international transit advantages and connectivity with other countries of the world. Their endowness with natural deep seas, huge petroleum deposits, fishing, and handling of iron ore and other natural resources, offers good advantages for jobs creation, industrial and commercial development in Cameroon.

\subsection{Data and Methods}

Data for this paper has been collected through a thorough combination of both primary and secondary material. Secondary information and research on existing documents, articles, journals and the internet, and audiovisual sources open the way for the identification of some key concepts on the development, urbanisation, and growth problems in Douala, Limbe and Kribi. Secondary data further provided an overview and in-depth knowledge of the extent of the problem of industrialisation, government policies and urban planning since the colonial period. Urban development agencies and the personnel of the city council and Ministry of Towns and Urban Development were also contacted for information on government urban development policy. Primary data was also generated from field surveys and observation of urban problems in these towns. Attempts to collect information on the government budget for urban renewal policies in Limbe and Kribi failed because of reticence of municipal council officials to deliver this data on grounds of suspicion. It is for this reason that historical data and secondary data for Yaounde and Douala have been extrapolated for references in some parts of the text.

\section{Expansion Constraints and Endangered Fortunes}

The physical setting and economic environment may handicap the growth of these towns. These include the site, prevalence of risk factors and problems resulting from industrialisation, development and population migration for jobs and services in Limbe and Kribi. These drivers will endanger ecological and cultural touristic attractions present in these sites such as natural beaches and gardens. Kribi has a dense humid forest that limits its expansion west ward. The low altitude relief of the town favours flood from oceanic waters. Several streams also obstruct the smooth expansion of the town. Limbe on the other hand has physical, natural and morphological constraints which limits its expansion. The town lies at the foot of Mount Cameroon and is characterised by Lava domes and accidented slopes that render construction works difficult and exposes its population and infrastructure to fatal landslides. Limbe is also adjacent to the Atlantic Ocean and frequently affected by mild Tsunamis and coastal floods resulting from seismic activities.

\section{Genesis of Kribi and Limbe}

Before the arrival of the Germans, the present site of Kribi formerly referred to as Lahove was occupied by an indigenous fishing population at the left bank of the Kienke River. The Germans signed a series of treaties with the traditional authorities (Mveng, 1963) for reasons of security of their installations, investments and influence. This was to enable them have full control of the site and access way via the Kienke river for exploitation of the Southern Cameroon forest up to the Congo Basin. In 1899, the Germans launched a war against the indigenes and established a military base to gain total control of commerce under the Gesellschaft sud-Kamerun. This opened the way for the installation of European firms in Lahove whose mission was to export the local products to Europe. An indigenous settlement then developed along a European quarter that became the engine of the spatial expansion of Kribi.

Following the defeat of the Germans by France and Britain in the first and second world wars, Kribi gained an administrative status under the French. The growth and expansion of economic and commercial activities, led to the first population influx from other parts of Cameroon into Kribi and the steady urban expansion of the city. Kribi thus experienced the birth and expansion of quarters such as New Bell, Petit Paris, Afan-Mabe, Mokolo, Mboa-Manga (an indigenous quarter) which today represents more than 80 percent of the town's urban build up space.

Limbe on the other hand was founded in 1858 by Alfred Saker a British Baptist missionary. Since then, it has evolved in settled space, economic activities and population dynamics. The implantation of industries and other development projects in Limbe has been a priority of the Cameroon government and private operators but the method of natural resource exploitation in the last one decade is failing to respect the norms of protection and management of this coastal environment. 


\section{History and Growth Experiences of Douala}

\subsection{Douala Pays Its Debts?}

Douala was created in the $17^{\text {th }}$ century. The first occupants originated from Congo and were later joined by the Germans and the French in the $19^{\text {th }}$ and $20^{\text {th }}$ Century. The town in the past was the main port area, industrial centre and economic capital of Cameroon. The industrial development and expansion of the city further consolidated its self centred autonomy leading to less attention to the then satellite towns of Kribi, Tiko and Limbe which are today emerging as the foci of Cameroon's industrial expansion. The Kribi port that in 1912 was the most important in Cameroon declined in favour of Douala. Traffic in the Douala port by 1983 was 21.55 times higher than in Kribi (Ngandjui, 1986) and diverted dynamic migrants comprising Bamileke, Nigerians and other foreign nationals into the town. In 1925, the population of Douala was 5000. It is presently estimated at 2.1 million inhabitants and projected to double by 2015. The urban space has grown from 8600 ha in 1976 to 22,000 ha in 2003. The population of Kribi and Limbe are following similar imprints (Table 1, Figure 2). Today the rapid growth, uncontrolled expansion and multiplicity of problems in Douala have made the town to begin paying back the price of industrial monopoly.

\subsection{Crime Dynamics}

Douala with a population of over 2 million today represents 20 percent of Cameroon's urban population. Crime has become a preoccupying issue in this city that has a growth rate of $5 \%$, above the average growth of $2.3 \%$ in Cameroon. According to the judiciary police sources, the growth and expansion of Douala has been accompanied by increase in crime wave. Public media reports and crime victimisation surveys reveal that between 1998 and 2002, crimes registered by the littoral judicial police varied from 317 to 526 cases. It involved motorbike theft, corruption, violence on women, burgling and arm robbery, land disputes and money laundry. According to Ngomsi (2008), today an average of 30 crimes is committed per month. In these scenarios, feymaniac represents $28.9 \%$, gunshot aggression $26.2 \%$, robbery at homes $16.7 \%$, and physical aggression $13.8 \%$. Money, electronic devices, mobile telephones and recently digital devices, laptop computers and valuables in parked cars are objects targeted in several incidences. The rate of victimisation in Douala stands at $74.71 \%$. Workers of the informal and private sectors are the most vulnerable because it is belief they carry along money. Douala $5^{\text {th }}$ district (78\%) is the most hit and followed by Douala 4 (74\%) and Douala 3 (71\%) respectively. Insecurity is highest in unplanned quarters, poorly guarded play grounds and open spaces in New Deido, Nylon, Ndokoti, and the university zone, where urban disorder excels by $80 \%$ (Tiafack, 2013). These are densely peopled areas. The high level of crime committed in Douala during the February 2008 uprisings over high fuel prices and rising cost of living in Cameroon shows the magnitude of this problem.

More than $50 \%$ of the population live in unsafe haphazardly constructed houses and under-equipped neighbourhoods. Douala lacks a risk prevention plan, an enforced Master plan and development strategy. Consequently, many of its over 2 million inhabitants have illegally occupied buffer lands, and risks prone areas that are inaccessible to security agents for crime containment. In Kribi, a similar problem is faced. The past Master plans guiding construction have never been enforced.

It is feared these crimes might be relocated to Kribi and Limbe that are emerging to play major industrial roles. The twin attacks orchestrated by heavily armed ban of pirates in 2008 on Limbe and Kribi via the sea are signals and indicators of these happenings in future. Also, the attacks on Chinese contractors responsible for building the Kribi Deep Sea port during the laying of the foundation stone by President Paul Biya of Cameroon on October 2011, leading to the theft of the Model plan of the port, shows that crime is alive and discriminates against nobody. Presently, there is a high influx of job speculators into these towns following the announcement of many development projects.

Table 1. Population growth of Douala, Limbe and Kribi between 1925 and 2012.

\begin{tabular}{rccccccccc}
\hline Town & $1925-35$ & 1953 & 1964 & 1967 & 1976 & 1987 & 1998 & $2000-2004$ & 2012 \\
\hline Limbe & 3131 & 8025 & 15,919 & 19,525 & 26,988 & 44,561 & 46,203 & $11,6047(2004)$ & 140,982 \\
Kribi & NA & $3000(1948)$ & NA & NA & 11,286 & 21,500 & 32,460 & $48,800(2001)$ \\
Douala & 5000 & 124,000 & $170,000(1960)$ & NA & 458,426 & 809,852 & NA & $1,692,323(2002)$ & $2,100,000$ \\
\hline
\end{tabular}




\section{Urbanisation of Kribi and Limbe}

Towns in Cameroon are characterised by very high urban growth with Limbe and Kribi not excluded (Table 1, Figure 2). The rate of urbanisation in Cameroon is 5.0 percent per year, ranking it amongst the most urbanised countries in Sub Saharan Africa. Registration of man power needs in Buea showed that over 15000 job seekers have been indicated as unemployed, up from 8000 in 1999 (MINPAT, 2000). Limbe in the Buea neighbourhood is the likely future destination of this army of unemployed. Most of these populations are job speculators waiting for the development projects announced in the near future in these secondary towns to go operational.

Kribi from the period of German occupation has expanded rapidly and spread along the major highways that converge on the port area. The expansion began from New Bell near the commercial Centre with the influx of migrants and the successive installation of structures by the Germans and French colonial administration. Henceforth Petit Paris and Afan-Mabe (most rapidly expanding quarters) and Mokolo (the most densely people i.e. > 150 inhabt/ha) emerged with more influx of migrants from the hinterlands after the period of independence of Cameroon. Law no 56-146 of 3 November 1958 defined the boundaries of Kribi urban space. Its surface area was over 600 hectares and englobed Mboa-Manga, Upper Talla on the west bank of River Kienke, stretching to the Dipembe and Nanga-Njango streams on the Kribi-Ebolowa and Grand Batanga Highways. In the north it covered Ngoye-Wamie and Njamoue along the Kribi-Edea road, limited by rivers Wamie and Njamoue. Dombe along the kribi Lolodorf highway was also included.

Limbe, Kribi and Douala like many towns in Cameroon have a record for non respect of urban master plan enforcement. Faced with population growth (Table 1) and challenges, urban development plans were put in place to orientate the expansion. Limbe had its urban plan in 1973 (Figure 3). It defined industrial zones, housing areas and reserved the farms (Mile 2) as agricultural zones. In July 1967 a plan was adopted to demarcate the Kribi urban space from the situation in 1958 with caution to prevent the expansion of the town from affecting the coastal perimeter (Figure 4). Considerations in the planning were given to the industrial, commercial, administrative and protected zones, leisure grounds and residential area for about 13,500 people. Most of these plans suffered from concrete realisation as the infrastructure planned were not realized, faced with haphazard heaping and spread of settlements. Lack of access roads due to urban disorder reigned in Mokolo, and AfanMabe. Faced with difficulties in the implementation of previous plans, in 1980 another plan was introduced modifying the urban perimeter. This plan integrated Ngoye, Dombe, Mpangou and Bongadoue as residential areas. Mokolo, Afan-Mabe and Petit Paris where urban disorder thrived were to be restructured. According to studies carried out on Kribi, the demand for land titles was very high to show the degree of expansion of the town. Ngoye (33\%) and New Bell (20\%) were the most solicited quarters as these were planned areas, followed by Petit Paris (15.9\%) for its accessibility and commerce. Mpangou, Mokolo, and Mboa Manga were the least solicited for land because of urban disorder and refusal by indigenes to lease out their lands. Today, Talla, Ngoye, Mboamanga, and Dombe are new urbanisation fronts where demand for land for settlement and farming is high. Urban disorder reigns at Zaire, Nkolbiteng amongst others (Figure 4).

In Limbe (Figure 3), expansion is towards the West (Idenau, Limbe-Bakingili road), North East (Mile 4, limbe-Mutengene). Highly risky slopes are under intensive colonisation (Mile 2, Mabeta, etc.).

As the previous plans the 1980 plan failed despite efforts by the urban council to reinforce it. The plan never integrated huge development projects earmarked for Kribi such as the natural gas liquefaction factory, the Kribi Deep Sea port project at Batanga, handling of iron ore mining at Mamelles and the huge populations this will possibly attract in future. Today these projects have multiplied in number and are faced with the geographical constraints of space and lack of adequate equipments that meets today's exigencies of environmental management.

The 1987 population Census of Cameroon projected the population of Limbe at 94,354 (2000) and 140,982 by 2010 and 193,179 by 2020. Limbe is already the seat of two giant corporations (the National Refinery Company Ltd (SONARA) and the Cameroon Development Corporation-CDC). This only further highlights the Central issue of this paper.

\section{Envisage Development Projects: Facts and Figures}

Limbe and Kribi are today the focus of many development projects in Cameroon. These cities are being called upon to play important economic roles through heavy capital investments in many projects (Table 2) that will boost the image of the cities and the economy of Cameroon. 
0. Tiafack et al.

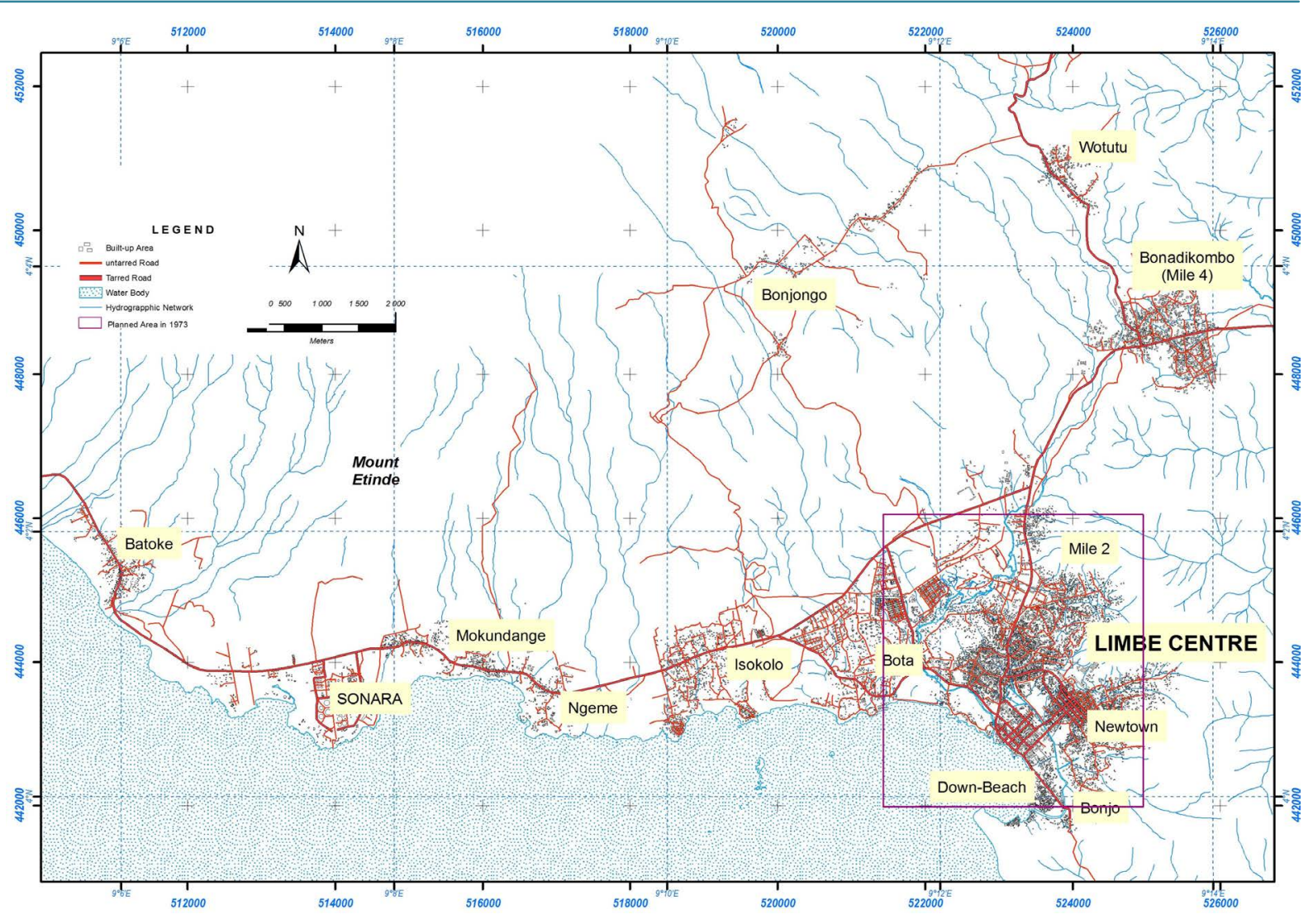

Figure 3. Layout of Limbe Town.

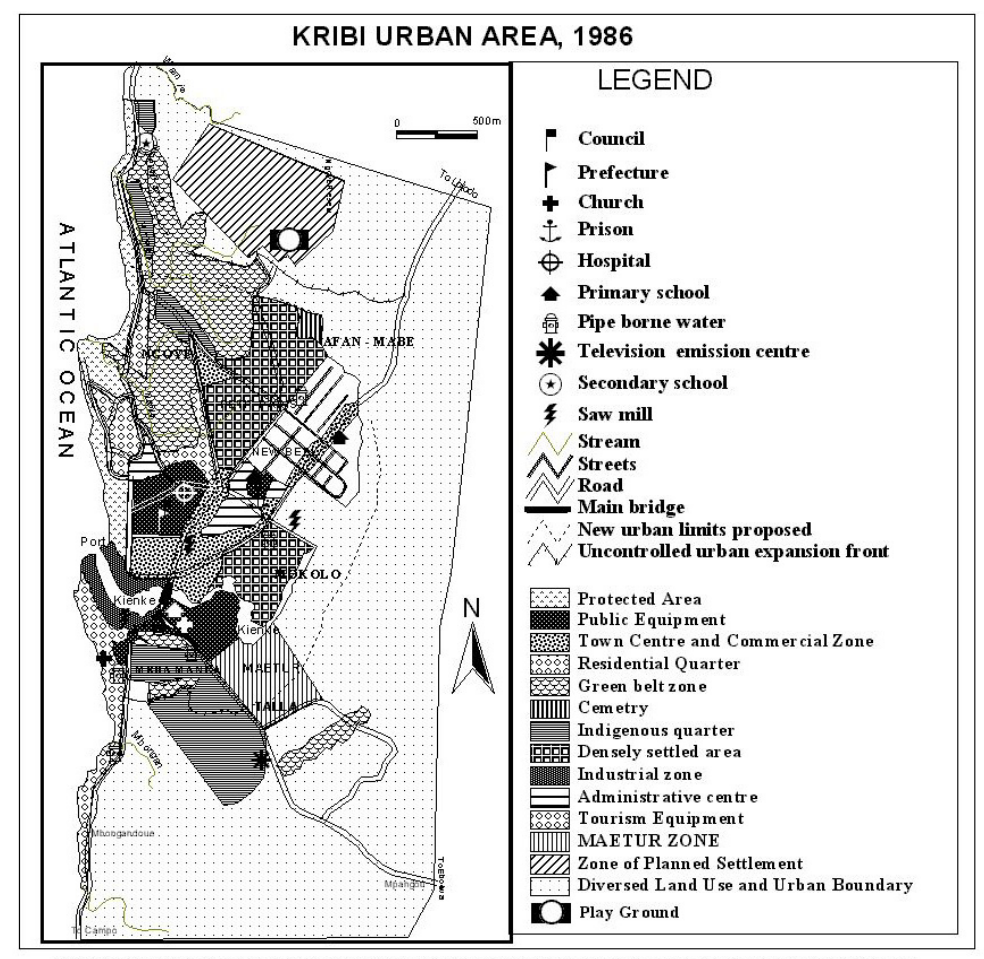

Source : Realised by authors from Aerial Photo of Grand Batanga-Kribi-Cameroon, 1982 and Ngandjui 1986

Figure 4. Layout of Kribi urban area. 
Table 2. Inventory of some projects for Kribi and Limbe, investment capital and fallouts.

\begin{tabular}{|c|c|c|c|}
\hline Place & Project and Partners & Investment Value & Fallouts Expected \\
\hline \multirow{9}{*}{ Kribi } & $\begin{array}{l}\text { Kribi Energy Centre (Gas factory)-Bipaga (Parenco, Rio } \\
\text { Tinto Alcan Group, SNH), America, Canada Sweden, }\end{array}$ & $\begin{array}{l}90 \text { billion FCFA } \\
\text { phase } 1\end{array}$ & 2000 jobs \\
\hline & Petrol Exploitation and refining (Total EMP/SNH) 2009 & 10,000 billions & 60,000 barrels/day \\
\hline & $\begin{array}{l}\text { Kribi Aluminium factory (Rio Tinto Alcan Group) } \\
\text { phase 1, July 29/2009 }\end{array}$ & 2500 billion FCFA & $\begin{array}{c}\text { Capacity } 930 \mathrm{mw}>30,000 \text { jobs } \\
\text { Kribi-Edea Railway, Highway, Sea port } \\
\text { development }\end{array}$ \\
\hline & $\begin{array}{l}\text { Mbalam Iron Ore Mining (Cameroon Iron SA and the } \\
\text { Australian Sundance Resource limited (ASX)) }\end{array}$ & $\begin{array}{l}12 \text { billion FCFA } \\
\text { (research works) }\end{array}$ & $\begin{array}{l}800 \text { million - } 1 \text { billion tons } \\
\text { Mbalam-Kribi Railway and Highway, } \\
\text { Aerodrome maintenance }\end{array}$ \\
\hline & $\begin{array}{l}\text { Mamelles Iron ore Exploration (SteelCam, } \\
\text { S.A and Swiss Banks) }\end{array}$ & 250 millions EU & $\begin{array}{l}300 \text { direct jobs and } 600 \text { indirect } \\
\text { Port development, Schools, roads, } \\
\text { hospitals, mine installations, energy }\end{array}$ \\
\hline & $\begin{array}{l}\text { Lolodorf Uranium Exploration and valorisation } \\
\text { (NU Energy Corporation Cameroon) }\end{array}$ & NA & $\begin{array}{l}\text { Road Maintenance, District } \\
\text { Hospital equipment, } 40 \text { jobs, }\end{array}$ \\
\hline & Deep seaport Complex (4 Ports) & 12 billion (research) & $\begin{array}{l}>4000 \text { jobs, promote tourism, } \\
\text { fishing, mining, }\end{array}$ \\
\hline & Chad-Cameroon Pipeline (COTCO) 12/06/2004 & 30 billion FCFA & $\begin{array}{l}\text { Water supply, schools, floods } \\
\text { control works, road maintenance }\end{array}$ \\
\hline & $\begin{array}{l}\text { Kribi Power Development at Mpolougue } \\
\text { Corporation (KPDC) 07/2009 }\end{array}$ & 135 billion FCFA & Jobs \\
\hline \multirow{8}{*}{ Limbe } & Gas factory by America & NA & Jobs \\
\hline & Deep seaport complex at Sokolo, 10/1995 & $\begin{array}{l}\text { \$ US } 350 \text { billion } \\
\text { Phase } 1\end{array}$ & 5000 jobs \\
\hline & Heavy Fuel Oil Thermal Plant (AES-SONEL Corp.) & NA & $85 \mathrm{mw}$ \\
\hline & Fishing Industry (China) & 35 billion FCFA & Fish production, job creation \\
\hline & Cement factory (AFCO South Korea) at Ngeme & NA & 600,000 tons/year, Jobs \\
\hline & National Refinery Company (SONARA), 12/1976 & 17.8 billion F CFA & 5 million tons/year (Petroleum) \\
\hline & $\begin{array}{l}\text { Naval Shipyard (CNIC) at Limbolah. Partners } \\
\text { (BDEAC, ADB,IDB and Netherlands), 1998-phase } 1\end{array}$ & NA & 4750 jobs \\
\hline & Football Stadium, 10/2009 (40 months completion) & 15 billion FCFA & Jobs, Entertainment (15,000 capacity) \\
\hline
\end{tabular}

Source: Multi-Media sources (Cameroon Tribune, 2009, internet, radio 2008-2012).

Considerable attention is being made on deep seaport complex development at Kribi and Limbe by 'Chantier Naval et Industriel du Cameroun' (CNIC) and foreign companies. Iron derived products such as aluminium and hydro-carbon will be handled by the Kribi deep sea port by heavy ships of over 250,000 tons, necessitating railway services. At Kribi, the ports will be four in number. The Kribi (existing port) and Grand Batanga will handle tourist activities, industrial fishing and other seaport transactions while the Lolabe and Lolabe 1 compartments will handle heavy seaport transactions such as hydrocarbon exportation, iron ore, bauxite and aluminium importation. Construction work for this port was projected to begin on March 2009. Super tankers and big vessels of capacity of more 250000 tons, will duck in the Kribi port complex when operational. Balam iron ore deposit will go operational in 2013 and exportation handled by this Deep sea port.

The Limbe Deep Sea port project on the other hand, is on the way and has a site covering over $2 \mathrm{kms}$, englobing the SONARA petroleum terminal and Chantier Naval Shipyard Terminal all in the Isokolo at the Kebe neighbourhood. The petroleum shipyard has a $1 \mathrm{~km}$ sea front, 100 hac water plan, and 60 hac of land. The port is considered by CNIC as the largest industrial project in Cameroon after the Chad-Cameroon pipeline piloted by the Cameroon Oil Transportation Company (COTCO). This port will support Tiko that handles sand, food, fishing and population transportation. Phase one of this project is already operational at 84 billion CFAF, and will attend 350 billion US dollars when completed in 2016. It will create 5000 jobs and boost economic activities in the South West Region of Cameroon. The project is piloted by National Ports Authority in collaboration with the Bank for African Development (BAD) that financed 140 billion FCFA for the project and Dutch enterprises and German firms. Feasibility studies have already been done. In 1995 the existing port went operational and 
enabled SONARA to export its products to Europe, USA and South America, producing 5 million tons per annum.

A contract has been signed with a Swedish Corporation on $16^{\text {th }} / 07 / 2009$ for mining of gas in Kribi Campo area. This contract reinforces that of the American and Total companies already operational in the town. The gas centre is located at Bipaga-Lokoundje. About 2000 persons will be employed by the project. AES Sonel will construct an $85 \mathrm{MW}$ at Dibamba with an evacuation post and high tension line for south network connection. Phase 1 of Kribi Gas Centre is evaluated at 90 billion FCFA.

Rio Tinto-Alcan Cameroon will carry out the extension and modernisation of aluminium production for ALUCAM and construction of the Nachtigal dam. The Kribi aluminium factory project will cover the Song Mbengué hydroelectric production dam that will produce $930 \mathrm{MW}$ and the aluminium factory itself that will have a capacity of 400,000 tons/year. The Canadian based Rio Tinto Alcan Group for Europe, Middle East and Africa, shall also participate in the construction of the Kribi Deep Seaport. The main sites for the aluminium factory, hydro electric dams and ports facilities were identified. The operational phase of this project depends on the execution of the Nachtigal and Lom Pangar dam project supported by Cameroon Aluminium Company (ALUCAM) and the Cameroon government. The foundation stoned for the Lom Pangar dam was laid on August 2012 by the Cameroon Head of State and Chinese Ambassador to Cameroon. The Kribi deep sea project will also depend on the Kribi Central Gas Station. This strategic project materialized in October 2005 through a letter of intent that was modified in November 2007 in efforts to extend ALUCAM. Over 30,000 jobs will be created (6000 directly and 2000 - 3000 yearly), to enforce the present 750 jobs in ALUCAM-Edea. Infrastructures such as a railway linking kribi-Edea, roads and the port will be developed to cope with the Aluminium extension project. The Kribi Aluminium factory valued at 2500 billion FCFA is being referenced as one of the most important projects in Sub Saharan Africa and will make Cameroon one of the leading aluminium producing countries in the World. A new factory of 1,000,000 tons is also envisaged in Kribi for the Adamawa bauxite reserves.

The Mbalam iron exploitation piloted by Cameroon Iron SA, and the Australian Sundance Resource limited (ASX) having 90 percent involvement, will also impact on Kribi. The Kribi deep sea port is expected to play a key role in the exportation of the iron as the Kribi-Mbalam $490 \mathrm{~km}$ railway and highway will ship the product. This project that is expected to create 2000 - 3000 direct jobs and 1000 permanent jobs by 2011 and 800 million to 1 billion tons of iron will impact on the Kribi sea port. 12 billion FCFA will be provided by multi-nationals for research works.

The Mamelles Iron Exploration (SteelCam, SA) project will also depend on the Kribi deep sea port for exportation of the product. The port zone is under construction for a $1 \mathrm{~km}$ anchor in the sea. This project will create 300 direct jobs and 400 indirect jobs and will cost 250 million EU from Union of Swiss Banks.

A huge forest land exists that obstructs the urban expansion of the town but offers timber exploitation potentials to the population, wood transformation industries and the Cameroon economy. The uncontrolled exploitation of this forest upsets the ecological balance. The forest also harbours industrial plantations (SOCAPALM) and forest reserve (Campo Faun, Kienke North and South forest reserves). Kribi has a bright future with regards to mineral exploitation as reveal by the ministry of mines and power of Cameroon and SNH amongst others. Mining prospecting in Kribi has revealed that Syenite or Rutle deposits (SICAMINES Sarl) exist at Eboundja, Iron or Nickel (CAMINA Sarl) at Ngovayang and Uranium or Gold (CAMINEX) in the East of Kimbi Ntem. The pipeline stretch from Ebome via Lolodorf in the outskirt of Mpanjo might posts a potential ecological risk. The lobe falls up to Londji via Ebouiyoe, Mpolougue along the coastline offer urbanization prospects judging from the rate at which land is purchase. These minerals will be mined and exported via the Kribi sea port.

Presently, Limbe harbours several enterprises. These include the Cameroon Development Corporation (CDC) created in 1949, the National oil Refinery (SONARA) in 1976, the Cameroon Tea Estate (CTE) in 2002, the AES-SONEL Energy Centre at Cape Limbo area in 2001, Mineral Water factory (Semmewater) in 2004 and Chinese fishing firms operating off shore. Installations for the construction of a cement factory at Ngeme-Mokundange, the Limbe deep seaport complex by CNIC, and works to expand SONARA will boost the port and industrial potentials of this city.

\section{Development Challenges}

\subsection{Pollution}

The industrialisation of a city is often accompanied by infrastructural development, job creation, influx of popu- 
lation, growth of businesses and services. Very often this leads to urban growth and pollution necessitating environmental impact studies. Kribi will likely suffer environmental pollution resulting from the Chad-Cameroon pipeline and handling of iron products if adequate monitoring is not done. In limbe, petrol exploitation and refining by SONARA is polluting the environment through gas discharge from ships, water contamination by hydrocarbon products, solid and liquid effluents from toxic chemical substances during repair operation (Njimonkut, 2006). The manufacturing of cement at Ngeme by AFCO—Korea will increase this problem if greater care is not taken for mitigation. South Korea intends to produce high quality cement with a capacity of 600,000 tons per year in Limbe beginning from 2011. Studies have shown that limbe and kribi are affected by pollutants from the SONARA petroleum refinery, palm products (oil and coconut) processing by CDC, food processing industries and thermal energy centres. In 2007, 1,424,190 tonnes of sulphur dioxide and 1,186,924 tonnes of carbon dioxide were emitted to the atmosphere by SONARA (Munyele, 2008). Agro-chemical products from the CDC Palm oil refinery and untreated toxic substances are discharged on land and water bodies at close range to population settlement (Tchoupo, 1994). Water samples from the Down Beach, SONARA Beach, and Idenau Beach analysed by the National Institute for Chemical and Biochemical Research have shown substantial amounts of hydrocarbons (benzene, toluene, ethyl benzene and xylene) present in the water, above the standards set by the World Health Organisation. These products are highly noxious and the handling might pose a problem to these environments and its population which are the heart of Cameroon's urban tourism. The urban dwellers are directly and indirectly dependent on these industries for employment, income and survival. Recent conflicts over the discharge of physio-chemical and organic pollutants on land between SONARA-Limbe and the populations of Bobende, Mokundange, Limbolah, and Batoke living near these industries, show the gravity of this problem.

Minerals such as bauxite, iron ore, uranium, aluminium, diamond, and petrol projected to be mined in Cameroon will be exported via the Kribi and Limbe deep seaports. The handling system has to take into consideration these problems to avoid high cost repairs after pollution. Business companies in Kribi and Limbe, will help these towns to achieve sustainable development by integrating the triple bottom line (economic efficiency, social equity and environmental sustainability) in their balance sheets. Reprocessing of waste, and involvement of health institutions capable of early diagnosis and treatment of personnel should be incorporated into this triple bottom line approach. All of this ushers in the issue of inner city greening health insurance for yet to be diagnose pollutants etc... Lessons from the incident of Minamata-Japan in the1960s where 1500 persons were seriously affected and 200 killed after consuming fruits contaminated by mercury from the sea are educating for Limbe and Kribi faced with pollution challenges. Studies on pollution of the Gulf of Guinea within which is located Limbe, Kribi and Douala have revealed that about 500 million tons of diverse waste, 1 million tons of biodegradable waste, 96,540 tons of dangerous waste and 2840 of non dangerous waste are discharged annually by industries and other activities on this marine ecosystem.

\section{Experiences of Nylon-Douala on Pollution and Lessons}

Nylon in South West of Douala harbouring the Bassa North and Magzi industrial zone along the Yaounde Douala Highway (road No. 3) and Douala Airport offers a test area for emerging problems at a scale that the Kribi and Limbe urban planners have to guide against faced with sustainable development challenges. Population pressure in this green belt zone is high and has been the outcome of steady population influx into Douala for economic activities. The Douala airport, neighbouring mangrove ecosystem and stream banks have been invaded by its population today estimated at 269,797 . Nylon is at pollution risk and has been at focus of intervention by the Douala urban council for demolition and other urban renewal works.

The first master plan of Douala was elaborated and published in 1959. Initially an attractive Green Belt forbidden from habitation, Nylon has become a high risk area in terms of diseases proliferation and pollution from industries, habitats and commercial grounds that makes the zone not good for human settlement. Early diagnostic reveal that it is a very filthy, marshy and inaccessible area. It is also highly polluted and unhygienic, poorly served with waste discharge facilities from the Cameroon Hygienic and Sanitation Company (HYSACAM). It lacks a drainage system for the evacuation of waste water discharged from houses and commercial structures. Reports from the Wouri health district and studies covering Douala in the last 3 decades have shown that malaria, cholera, diarrhoea, typhoid and other water borne diseases are endemic in Nylon, Ndogpassi 3 - 4, New Bell, and from streams and wells where the population depend for domestic and drinking water (Roumy, 1983, Medecins Sans Frontieres, Schmitz, \& Mendoza, 1993; Wambo, 2008). The same picture prevails in other parts of Douala suffering from poor sanitation and epidemics faced with industrial, market and domestic pollution as 
was the case in 1973, 1985, 1998, and 2004. An average of 1300 tones of Waste is produced per day in Douala with 500 tons cleared daily (National Institute of Statistics, 2002). This in addition to other forms of pollution makes the town unhealthy for population settlement. The nuisance from water and polluted air is quite disturbing to residents and visitors and has been a tough preoccupation of Douala development stakeholders (Ministries of health, urban planning, territorial administration, Urban Council, NGOs). These problems were not envisaged when Douala began its industrialisation pathway and should serve as lessons to Limbe and Kribi.

\subsection{Waste Production and Health Risks}

It is projected that waste production typical of Nylon in Douala will be a thorny problem necessitating action in these cities. The emerging industries in Limbe and Kribi, auxiliary activities and enterprises, migrant households, new service places such as administrative structures, markets and hospitals, will likely produce organic and biotic products, liquid and gas waste, beverage and aerosol cans, plastics, metal scraps, papers, ceramics, glasses, and other types of non-degradable substances that will leather the environment if HYSACAM rubbish clearance bins, landfills and treatment activities are not intensified. Legal action against waste producers (companies, households, traders, civil servants) and transparency in the mismanagement of waste by municipal councils and definition of roles for stakeholders must accompany the investments in this sector. A major problem in Douala and other towns in Cameroon plagued by waste disposal problems has been the ill distribution of waste facilities (thrash cans, bins), shadow roads that block access to waste collection points, poor management and conflicts in roles between the government ministries, councils and municipalities, and a recalcitrant population that consistently leathers the streams and open spaces (streets, homes, markets, playgrounds, motor garages and parks, administrative areas and state funded housing estates) with garbage and liquid waste (Tiafack et al., 2009). Waste collection in Limbe is hindered by poor maintenance of vehicles and inadequate fuel supply, insufficient garbage cans and an indiscipline civilian population.

Spontaneous discharge of waste into water and open spaces is a problem to the health of the urban population especially the low income groups that occupy low class residences ill served with health facilities. The poor in Centre-Ville, Petit Paris, Afan Mabe, Mokolo, New Bell, Mboa Manga in Kribi and Motowo, Church Street, New town, and Cassava farm in Limbe are plagued with waste pollution problems. This population is vulnerable to environmental diseases such as malaria, cholera, diarrhoea and typhoid typical of Douala. Medical reports from Mile 1 District hospital, Bota Hospital and Batoke Health District in the West Coast shows that a total of 22 patients from Mokundange and 12 from Batoke in 2008 suffered from typhoid fever. These are populations that consume water from the ocean that might have been contaminated by industrial effluents. The incidence is lower amongst the Batoke population because the population consumes water from Mt Etindi.

Solid and liquid waste disposal facilities are insufficient in these quarters. Waste as the Nylon case study portrays is a catalyst that breeds vector responsible for these diseases and resulting crisis. In Bamenda the urban council authorities have gone a mile stone in public hygiene improvement by creating equipped public toilets and imposing a legal fine of 2000 CFAF to law breakers. This is a sustainable lesson for Limbe and Kribi. Population growth and emerging enterprises will necessitate a good sewage disposal system especially in kribi that has a low altitude terrain. The Dockyard Canal (artificial channel) constructed to drain the eastern hills of Limbe town are sustainable efforts and point of departure for solutions to this challenges.

\subsection{Water and Health Risk}

Recent studies in kribi and Limbe have shown that these towns suffer from health hazards resulting from difficulties of potable water supply, spontaneous growth of population and houses, poor sanitation and lack of a good drainage system. These problems are acute in Kribi because of the low relief that makes water circulation difficult in some places. It also results from uncontrolled discharge of waste on streets and water in both towns. When floods occur during the rainy season the situation is worsen by rubbish from toilets that is discharged to the surface. Dirty water from streams and marshy areas also invade homes and destroy property.

The population of Kribi and Limbe residents depend on different sources for water. In kribi these include water from privately owned wells which represents $27 \%$, rivers $16 \%$, pipe borne water $20 \%$, bored holes $30 \%$, and source water 7\% (Djilo, 2008). The water from most of these sources is untreated thus exposing the population to water borne diseases such as the cholera epidemic of 2004 in Kribi. Water facilities initially scheduled for few residents have been over pressured by incoming migrants. In Limbe they are 76 public taps operated by the Na- 
tional Water Corporation (SNEC) now known as CamWater with 27 closed down. The world health Organisation recommends that 100 litres of water be used by an urban dweller per day. This means that $4800 \mathrm{~m}^{3}$ is needed by the Kribi population of 48,000 , more than $15,000 \mathrm{~m}^{3}$ for the Limbe population of 140,982 . Lack of access to safe water and sanitation, indoor and outdoor air pollution, and exposure to chemicals will increase the burden of diseases in Kribi and Limbe.

\subsection{Risk Dynamics and Challenges}

The ocean upon which Limbe and Kribi thrives faces the risk of floods and mild Tsunamis even though it offers opportunities for tourism, domestic and industrial fishing, mining exploitation and sea navigation. The expansion of Limbe urban area is handicapped by two main natural barriers that make the town vulnerable to risk. These are the Atlantic Ocean (10 - $20 \mathrm{~m}$ depth) to the South and Mount Cameroon (4095 m high) to the North. Limbe has an annual rainfall of $4050 \mathrm{~mm}$ and lies close to Debundcha that has a rainfall of $1000 \mathrm{~mm}$ per year. The sea presents wide risk of floods that often invades parts of Limbe town. Rise in the sea level, seismic tremors or heavy rainfall accounts for these floods. The Mabeta and Ngongkeka streams and Limbe River channel are densely population and prone to floods and future disaster. Cassava Farm, Clerks Quarter, Down Beach, Church Street, parts of New Town and Mile 1 are vulnerable to floods and landslides. These areas have altitudes varying from 0 to 4 metres above sea level. The topography of Kribi is flat and relatively low in altitude from the sea rendering areas such as Mpangou, Ngoye, Talla and Kienke neighbourhoods also vulnerable to risk of flood origin. West of Kribi is also covered by a dense equatorial forest restricting the expansion of settlement. Risk of natural and social dimension will likely increase in Kribi and Limbe in future especially in haphazardly constructed habitats and highly congested areas. During the Limbe (2001 and July 2003), Kribi (2000) and Douala (2000 and 2001), floods caused by heavy rainfall and surface running water occurred leading to mortal accidents and heavy destruction of property and infrastructure. During these incidences, 23 victims were reported in Limbe and 3 in Douala. Flood risk with wider effects is thus impending in anarchically occupied spaces against all planning rules in these earmarked industrial towns. Studies on landuse and zoning in Limbe, shows that presently, about 258 services and infrastructures are placed at risk zones with threats of different nature (Table 3 , Figure 5).

These services and installations are vulnerable to lava, lahar, rockfall, floods, tidal waves, landslide, seismic activities and gas hazard. These studies on risk in Limbe (MINATD, 2008) also reveal that houses are often abandoned because of floods (60.1\%), landslides (30.6\%) and other risks (1.3\%). The distribution of areas affected by floods shows Church Street (35.4\%), Down Beach (30.9\%), Lower Cassava farm (13.2\%), Cow fence (12.2\%), Poto Poto (8.2\%), and Mowo (0.8\%). Landslide risk is recurrent at Upper Cassava farm (35.4\%), Unity Quarter (30\%), Mowo (20.7\%), and Mbende (10\%).

Table 3. Census of services and infrastructures at risk in Limbe Council area.

\begin{tabular}{|c|c|c|c|c|c|}
\hline \multicolumn{6}{|c|}{ Stakes and Threats of Risk in Limbe Council Area } \\
\hline Risk Category & Infrastructure Type & $\begin{array}{l}\text { Number } \\
\text { Affected }\end{array}$ & Risk Category & Infrastructure Type & $\begin{array}{l}\text { Number } \\
\text { Affected }\end{array}$ \\
\hline Potable Water & Water Supply & 10 & & Gas Stations & 1 \\
\hline \multirow{3}{*}{ Economic Services } & Trade & 4 & & Electrical Post & 78 \\
\hline & $\begin{array}{l}\text { Finance } \\
\text { Industry }\end{array}$ & 9 & \multirow{4}{*}{$\begin{array}{l}\text { Administration and } \\
\text { Security Services }\end{array}$} & Prefecture Office and Council & 4 \\
\hline & Tourism & 17 & & Justice Office & 1 \\
\hline \multirow{3}{*}{$\begin{array}{l}\text { Communication and } \\
\text { Telecommunication }\end{array}$} & \multirow{3}{*}{$\begin{array}{c}\text { Post Office } \\
\text { Radio and Television } \\
\text { Telecommunication }\end{array}$} & 1 & & Health Structures & 7 \\
\hline & & 3 & & Prisons, Law Order Posts & 2 \\
\hline & & 6 & \multirow{3}{*}{$\begin{array}{l}\text { Population } \\
\text { and Housing }\end{array}$} & Religious Structures & 5 \\
\hline \multirow{2}{*}{$\begin{array}{c}\text { Education and } \\
\text { Research Services }\end{array}$} & Research Centre & 2 & & Entertainment Halls & 1 \\
\hline & Schools & 63 & & Stadium & 1 \\
\hline \multirow{3}{*}{ Transport Services } & Motor Parks & 1 & & & \\
\hline & Bridges & 28 & & & \\
\hline & Sea Port & 2 & & & \\
\hline Energy Services & Fuel Stations & 4 & TOTAL & & 258 \\
\hline
\end{tabular}

Source: Ministry of Territorial Administration and Decentralisation (2008), RPP Report. 


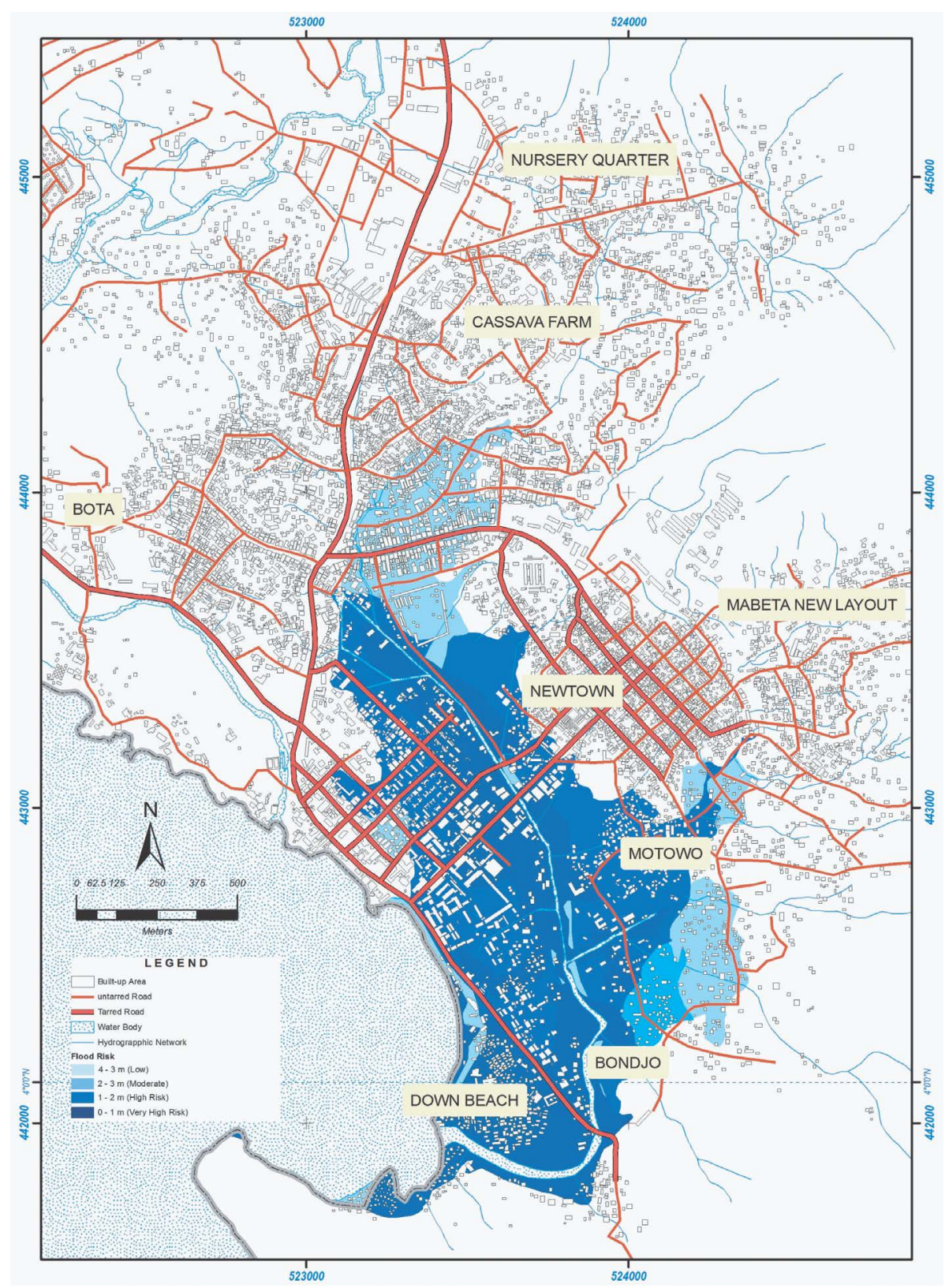

Figure 5. Modelling of Flood Prone areas and location of services.

Risk of Volcanic origin is also impending if urban disorder prevails in Limbe face with industrial development and urban expansion. Lessons from the 1999 and 2000 eruptions of Mount Cameroon have shown that fluid lava often flows down slope to the Atlantic sea. For now the area where future earmarked industrial projects (cement factory) and public edifies and installations such as SONARA, the Deep Sea port, Ship yard and other facilities are located do not post much risk of location because of small volumes of fluid lava flow. However if larger quantities of lava flow to invade distant areas from the vent, this will be dangerous to these structures. Also, if greater attention is not taken and future population settlements concentrate along the foothills of small Mt Cameroon, an imminent risk will lead to high cost investment in population evacuation and resettlement. Lessons from historical lava flows show that in 1815 lava flow stopped at Mapanja West of Limbe Town (Zogning (1994) citing MINPAT, 1986), 1868 lava stopped at Bavenga Village in same the area. 1922, 1000 hectare of forest, hundreds hectares of plantation lands and houses were destroyed before the lava was cooled by the sea, 1959 and 1982 Bakingili village was threatened, and 1999 and 2000 hectares of forest, oil 
palm plantations and road infrastructure were destroyed and Bakingili village inhabitants evacuated. The violent earthquakes produced by the eruptions also threatened the Limbe population.

\section{Experiences of Douala and Yaounde in Flood Management}

The city councils of Douala, and Limbe have in the past embarked on dredging works to prevent the re-occurrence of disaster faced with industrialisation, urban sprawl and population growth. The stream channel from Cites de Palmiers to Grand Moulin in Douala, was dredged by 2004. Similar works have been done in South Eastern Nylon, Bessengue, Yabassi, New Bell and the Ndog Passi Market. 14,759 m of urban stream channel have been dredged out of the $70 \mathrm{~km}$ targeted by the year 2010 in Douala (Zephania, 2008). This to prevent floods disasters in the already congested Makepe, Ndogpassi, Bessengue and Mbopi flood Basins. The city council is also embarked on widening of stream channels, building of embankments, construction of levees, and periodic recruitment of youths for clearing and cleaning of water ways. These are also pre-emptive measures to reduce the occurrence of floods and run offs that far exceeded the carrying capacity of streams and the sewage system. High cost defensive works against floods of this nature organised by the Douala city council and ministry of urban Affairs should serve as signals of an impending danger to Limbe and Kribi being called upon to play important industrial and economic roles

Yaounde the political capital of Cameroon is undergoing similar scenarios faced with rapid urbanisation. Past floods resulting from uncontrolled installation of development projects and population settlement along marshlands, the Mfoundi River and stream channels is costing the population and city council lots of problems in terms of human lives and property lost, infrastructure destruction and state financial resources. 21 billion CFAF to be spent in two phases is earmarked for the widening and construction of the Mfoundi channel before 2035. With huge investments projects earmarked for Limbe and Kribi, the re-occurrence of floods will likely cause similar scenarios to populations, public edifies and economic investments installed at risk zones, if preventive measures are not taken at the onset. Scientist predicts a 1 metre rise in sea levels in a hundred year to come. The impact of this rise will likely be a problem to populations and investments located in marshlands within Kribi and Limbe that are adjacent to the Atlantic Ocean. Flood risks are rampant along the Limbe coastline measuring 500 - 700 width by $2250 \mathrm{~m}$ length and 0 - $4 \mathrm{~m}$ altitude. The Down Beach and Jenguele Streams in Limbe were dredged and widened after the 2001 disaster. The raising of courtyards, lining of pure earth bags, infilling using volcanic rubble in low class quarters in Limbe and Kribi are further indicators of these crises. These risk zones are the most solicited by poor migrants resident in these towns for jobs faced with high rents in safe areas. They have been a high influx of job speculators into limbe and Kribi. These populations faced with poverty and high cost of living either locate in flood prone areas where houses are cheaper to obtain or occupy the rich volcanic soils on slopes vulnerable to landslides as is the case of Limbe to produce crops for the growing urban population. Development planners should be conscious that floods will cause a heavier or considerable damage on lives, private and public property in very densely settled areas if not well handled face with large influx of population for jobs in Limbe and Kribi.

\subsection{Managerial Challenges}

Limbe is the third largest in Cameroon in terms of custom revenue generation to the state. The creation of projects being announced for the cities of Limbe and Kribi will enrich the revenue of these towns. The state should create adequate financial resources, provide non corrupt administrative staff and law enforcement personnel to manage and protect the resources to be put in place by the government for development. This might avoid the situation of Douala. 622,360,000 CFAF is the working budget for the Kribi urban council, 434,060,000 CFAF the functioning budget and 188,300,000 CFAF investment for 2009 for the earmarked metropole. These amounts are too small compared with the roles they are called upon to play. The limbe Urban Council budget has been fluctuating between 900 and 1000 million FCFA between 1994-1999, with 574.7 to 435.3 million FCFA. The fiscal budget went up to 1.5 billion FCFA in 2000-2001 an indicator that major capital investments can handle the demands of future growing populations. The major projects being announced in Limbe and Kribi will enlarge the revenue base of these towns, necessitating transparency in management faced with a highly corrupt environment.

\subsection{Tourism Challenges}

Kribi and Limbe are endowed with fine sand beaches, colonial vestiges (German, French, and British) and hotels. 
These ecological aesthetics have to be preserved for tourism and their public hygiene. The lighting system, urban road network and infrastructures have to be improved to cope with the projected problems. The Kribi and limbe urban councils have announced a beach management plan to preserve the touristic beauty and activities in these towns faced with possible problems of industrialisation and artificialisation of these ecosystems. The beaches of Limbe and Kribi, tourist attractions along river Kienke-Kribi, Wildlife Centre and Botanical Gardens-Limbe face dangers of possible sprawling urbanisation and risk if not protected. The Lobe falls at the environs of Kribi are considered a UNESCO World heritage. It harbours projects and will likely face managerial problems (Tchawa et al., 2004). In Kribi, the Batanga Mayi and Mabi Nguma cultures are being endangered by sprawling urbanisation. For sure the government and the local councils may not invest and propose refined touristic products, so there will be the need to turn and encourage private individual/sector entrepreneurship.

\subsection{Urban Disorder}

The urban disorder that often accompanies the creation of a project, growth of population and activities in Cameroon towns (Plate 1, Figure 6) has characterised Limbe and Kribi and needs prevention.

Almost all state lands in Kribi and Limbe town have been occupied with illegal land titles established by land speculators. This was highlighted by the minister in charge of state property and discentralisation-Emmanuel Edou during a visit in Kribi on March 2009 where he noticed the illegal occupation of state lands in Lolabe and Mboro by urban dwellers and land speculators. These mal-practices are likely going to hamper the efficient planning of these towns faced with many development projects, population growth, and development of services such as commerce, transport, education, amongst others that may develop in these towns. Of recent (September 2009) seminars were held in Kribi to sensitize the population on better management of land. This shows concern about the prevalence of urban disorder in Kribi. The resources of the Kribi urban council have been thinned down to control urban disorder. Lots of these urban disorder cases are orchestrated by government officials, political leaders and business men that have legally occupied several hectares of state lands through corrupt practices. It is thus the political will of the government that has to determine the destiny of these towns as the land disorder observed is planned and organised by the actors involved. Lands adjacent to Maritime areas are government lands that are forbidden from occupation by the population (Plate 1). Contrary to the picture in several West, East and Southern African Coastal towns, Kribi and Limbe in Cameroon show rare situations where the population has occupied the coastline.

\section{Development Options}

Cameroon's development policy and option has been that of decentralisation, socio-economic development and elimination of all forms of regional disparities. Several options have to be put in place to prevent the occurrence of problems of the magnitude typical of Douala and Yaounde in Limbe and Kribi in the near future. These include improvement in transport, prevention of crime, risks, and urban disorder amongst others.

\subsection{Transport Reforms}

Successful industrial cities in the world have railway services that facilitate the flow of manufactured goods, raw material and population (labour, market). Linking Kribi and Limbe to other parts of Cameroon with this service is indispensable. Problems of congestion will be reduced in the long run as populations from long distances such

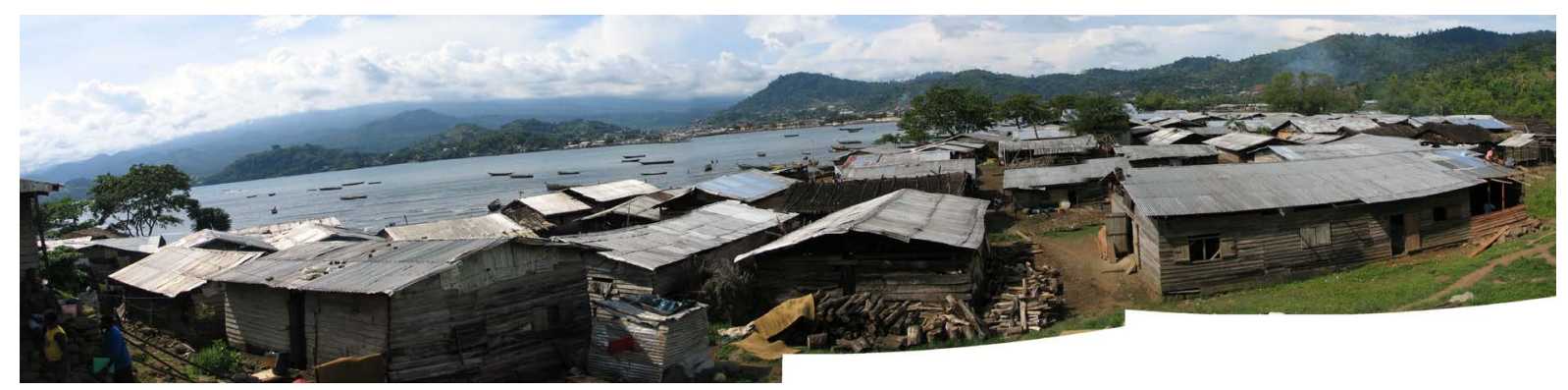

Plate 1. Partial view of haphazard settlements along the Limbe Coastline and fishing boats and canoes in the sea at Mabeta. 


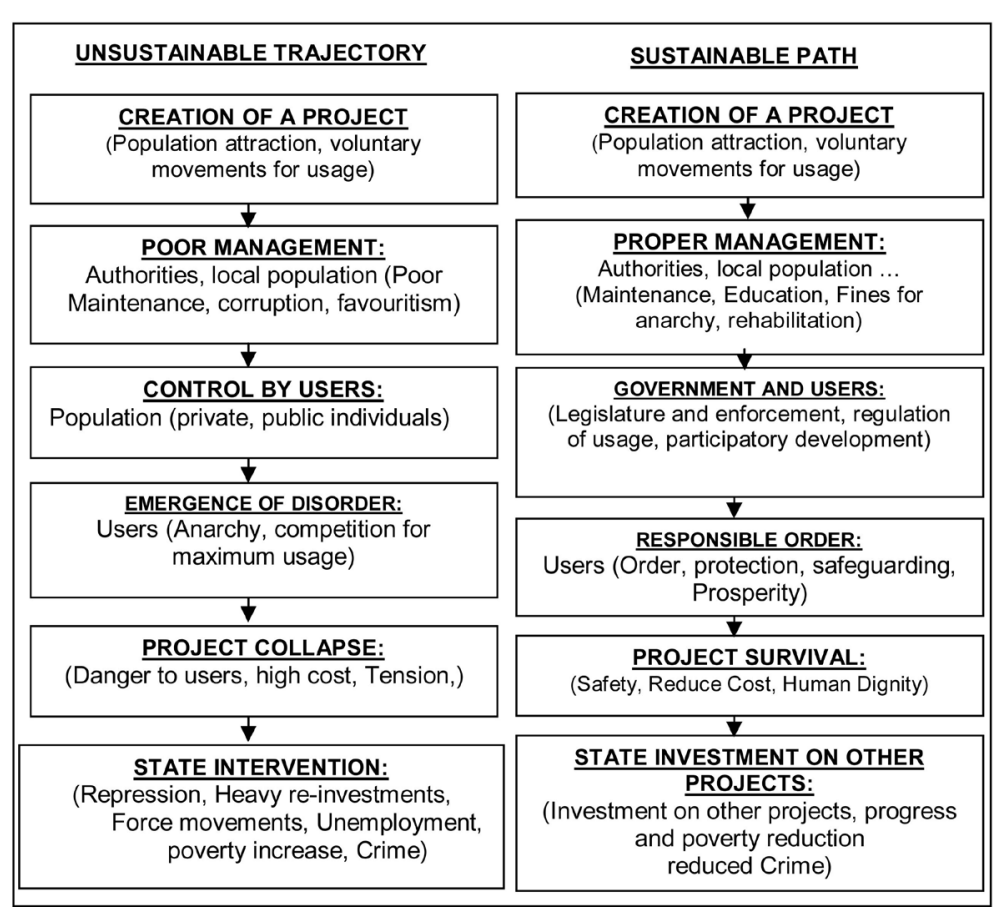

Figure 6. A model of urban disorder in Cameroon. Source: Conceived by Ojuku, 2012.

as Ebolowa, Yaounde, Douala for activity in Kribi and Mutengene, Tiko, Buea, Kumba, Douala for work in Limbe, will commute in the towns.

The September 2009 train and railway incidents in Yaounde that led to the death of 7 persons and injury of over 250 people in two successive days should serve as lessons of a poorly maintain railway system. The Cameroon government has currently announced the putting in place of a modern railway system by 2035 and a master plan to be piloted by South Korea. Edea and Mbalam are envisaged to be linked to Kribi by railway. If such services are put in place to foster industrial development, they should be regularly maintained and pedestrians kept out of these rails as is the current practice in Yaounde and Douala. In most industrialised towns of the world railway lines are sealed from public usage for circulation.

A good transport network is a key ingredient for economic development and social cohesion. If these services are inadequate, spatially discriminated, poorly conceived and maintained as typical of Douala and other towns in Cameroon the industrialization of Limbe and Kribi will pose considerable problems of circulation. The Cameroon Urban Transport Company (SOTUC) that existed in Douala and Yaounde prior to 1994 or the current private bus services in these towns "Le BUS" should be programmed for limbe and Kribi to facilitate collective public transport in future. The routes should be widened and well planned at the onset to accommodate car parks and other forms of transport and users. Handicapped persons and pedestrian lanes, bicycle and small scooters "bendskin" lanes amongst others should be created as observed in other industrial towns in the world. This will curb transportation disorder, traffic congestion, insecurity and social tension in buses and township taxis in future faced with newly acquired wealth from factories etc. It will also facilitate the safe movements of populations and delivery of goods and service; reduce time and cost of travel between complementary areas of these towns.

\subsection{Crime Dynamics and Mitigation Options}

Well planned crime mitigation posts to control emerging crimes are indispensable for Limbe and Kribi. If inspiration is drawn from facts emerging from studies in Yaounde and Douala that crime often stems from: crowded neighbourhoods, poor street lighting, inadequate recreation..., the emerging polarised towns of Kribi and Limbe will not fall again into the same trap. The creation of enterprises in these towns will likely attract the unemployed poor from neighbouring Douala, Yaounde, Mutengene, Kumba, Edea and other parts of Cameroon. Nu- 
merous migrants will likely increase crime waves, necessitating appropriate social institutions to contain such situations. Sea and inland crime risk in Limbe is high with Mutengene at the neighbourhood a prime supplier and criminal hideout. 3 Boats were offered in 2009 by the Cameroon government to reinforcement the Limbe maritime custom brigade to fight pirates. A maritime security conference on the Gulf of Guinea piloted by the American government took place on the $08^{\text {th }}$ of September 2009. This followed Acts of piracy that are on the increase in the Gulf, necessitating maritime countries of the region to be involved in this fight to protect foreign investors' investments geared towards the development of the region. Synergy for future joined regular military patrols by countries along the Gulf of Guinea is an option for these security concerns.

\subsection{Pollution}

Sustain waste disposal facilities and safe drinking water supply for the population is in high demand. Population growth and emerging enterprises will necessitate a good sewage disposal system especially in Kribi that has a low altitude terrain. Waste disposal points and treatment facilities are needed to protect the population from haphazard waste dumping and pollution nuisance around habitats. Green belts are also needed to replace the ecology damaged by heavy projects. The Kribi Urban Plan of 1967 and 1982 made provision for a Green belt zone even though this plans were never enforced (Figure 2). Local committees for environmental management with self-initiative projects for their own welfare will greatly enhance collective belonging and performance. In efforts to control industrial pollution, in 2005, enterprises involved in industrial activities in Limbe opted to construct a series of organic effluent discharge channels. The non respect of laws regulating environmental protection by industrial enterprises and failure to reinforce these laws by the state due to bad governance and corruption in Cameroon for the past two decades has been the root of these problems. A concrete policy by the state to better govern and manage the coast, periodic environmental impact assessment and monitor of industrial activities and their contribution to national development and poverty alleviation amongst the population is a sustainable option. The Ramsa Convention and Johannesburg Conference of 2002 on sustainable development amongst several others laid emphasis on Integrated Management of the Coastal Zones (IMCZ) and should be a preoccupation of Cameroon faced with the development of Limbe and Kribi coastal towns to reinforce the economic role of Douala.

\subsection{Technological Risk Reforms}

Fire Brigade cells evenly spread out in the town and well equipped to intervene in time during fire extinguishing operations should be created. It takes between 30 to 2 hours to intervene when a fire occurs in Yaounde between Biyem Assi and the Essos fire station and an average of 1:30 minutes from Mokolo due to traffic congestion and narrow roads that retard easy circulation of fire fighting tankers for rescue missions. In Douala the situation is worst where traffic congestion is very high. At this time duration everything being equal, no property on fire can be rescued. Complaints such as lack of fuel and water in fire fighting tankers when an incident occurs are often raised by the service. The profound economic crisis that hit Cameroon in the 1990s and 80s laid a platform for corruption and poor management and governance that have undermined this services and infrastructure. The crisis also fuel urban disorder in all urban sectors leading to a plummet in the quality of public infrastructures executed. Fire accidents may occur at homes, market places, and public institutions as has been the case in Douala. This necessitates free ways for quick intervention by fire fighting brigades and insurance services for civil protection.

\subsection{Control of Urban Disorder}

\subsubsection{Victims of Development}

Localities and development projects at the vicinity of Limbe and Kribi will pay the price of sprawling urbanisation if not integrated in the planning system to absorb shocks of urban expansion. These include Lokoundje, Nyete, Akom II, and Bipindi in the environs of Kribi town, Mile 4, limbe 3, Bakingili in Limbe, and the large industrial plantations adjacent to these towns such as SOCAPALM and HEVECAM in Kribi, and CDC Pamol in Limbe.

The ministry of Housing and Urban Development via MAETUR and FEICOM all government agencies should target these zones with sustainable development projects, realistic plans, and should use draconian meas- 
ures where necessary to crack down disorder and illegal occupation of state lands in the maritime zone by land speculators.

\subsubsection{Price of Redressing Urban Disorder}

The experiences of redressing urban disorder in Yaounde and Douala — the major towns of Cameroon have been very bitter and are costly options to avoid by a developing country facing many growth problems. It is not only costly to the state that reinvest huge financial resources to the problem (Table 4), but inflicts heavy damages, losses and sufferings on the victims during and after the operation in a context of economic and social crises. Many urban dwellers lost valuable items such as house equipments, commercial articles, and money to vandals and bandits during the operation.

\section{Conclusions}

The development of ports and industrial towns especially those located along the coastline as the case of Kribi and Limbe is important as these towns constitute the nerve centres of internal and international exchange (Figure 7). This development goes with many dynamics such as densification of its population and activities,

\section{Table 4. Scaling government urban industrial policies in Cameroon.}

\begin{tabular}{cc}
\hline Scale Category & Policy Target \\
\hline Diamond & $\begin{array}{r}\text { Creation, Development, Decentralization of authority and Sustainable Management of all } \\
\text { Cameroon maritime towns, river towns, and inland towns }\end{array}$ \\
Golden & $\begin{array}{c}\text { Development and Sustainable Management of all coastal and river towns of Cameroon } \\
\text { Development and Sustainable Management of Douala, Kribi, Limbe, Tiko (coastal towns) and } \\
\text { Silver } \\
\text { Bronze }\end{array}$ \\
Development of Douala, Limbe, and Kribi coastal towns
\end{tabular}

Source: Proposed by Ojuku, 2012.

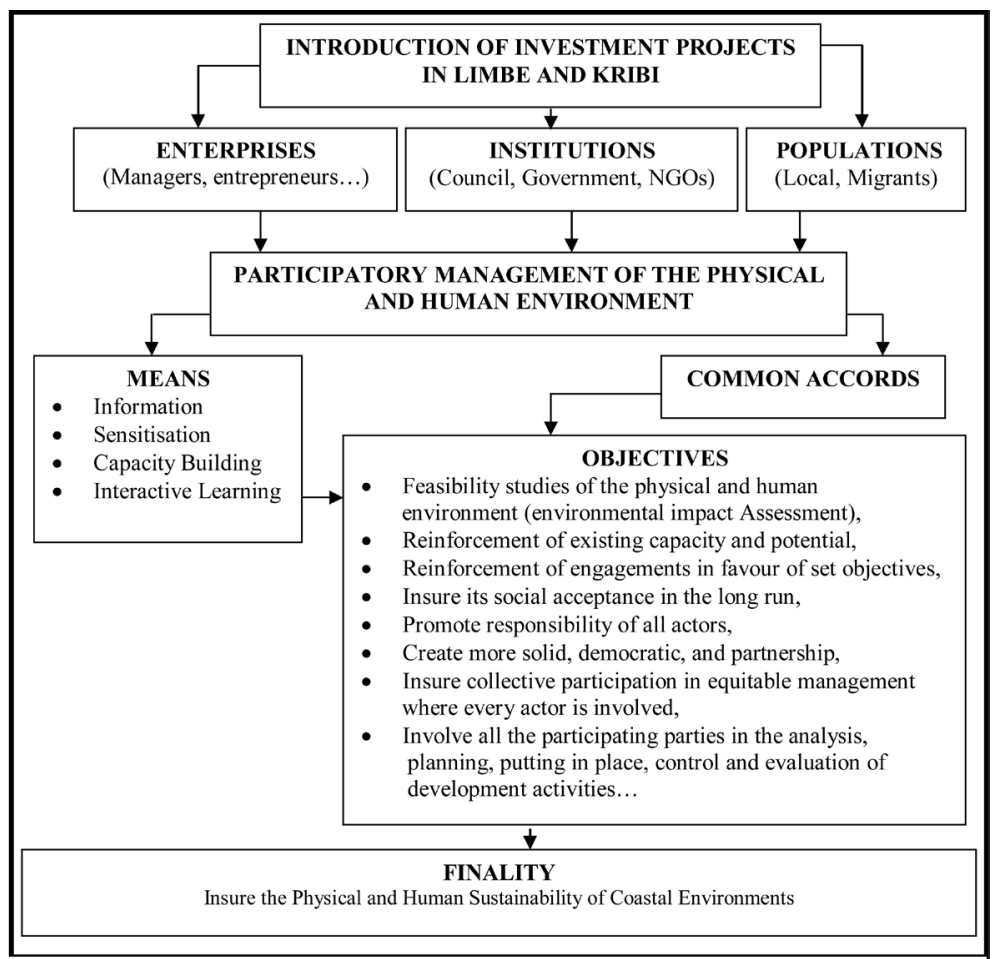

Figure 7. Framework for participatory management of Limbe and Kribi. Source: Realised by Ojuku from Participatory Management Documents of Cameroon (1999). 
spontaneous occupation of land, land use problems, urban disorder and social tension. One observes that investment projects in Limbe and Kribi have started attracting and grouping huge dynamic populations and socio-economic activities that trigger economic development alongside environmental problems and social tension. Actors involved in investment and the development of Limbe and Kribi should incorporate the triple bottom line (economic efficiency, social equity and environmental sustainability) in their balance sheets, failure of which the sustainable development of these cities and their population will be difficult to achieve. Coastal towns and their port, industrial and commercial activities have from historic times been the nerve centre, source of strength, and economic might of many countries and above all their window to the rest of the world. The development and sustainable management of Limbe, Kribi and other coastal and river towns such as Tiko, Mamfe, Edea and Yabassi, will strengthen Douala the industrial hub of Cameroon and boost up the image of the country in development with the rest of the world. Developing all maritime and inland river towns of Cameroon (Table 4) should be a long term goal of the Cameroon government as this will position Cameroon among the leading industrial nations of the world.

The current difficulties faced by Douala in its growth trajectory should serve as lessons for emerging Limbe and Kribi. If the huge investment projects earmarked for these towns are well managed; the problems that often accompany industrial growth prevented and the fall outs of development well harnessed for the interest of the population, this will elevate the status of Cameroon to an industrial power not only in the CEMAC region and Africa but in the world. It might in future place Kribi and Limbe of Cameroon in a prestigious position typical of many industrial cities such as Johannesburg-South Africa, London-UK, Rotterdam-Netherlands, Shangaï-China, and Osaka-Japan amongst others that began from this point after the industrial revolution and are today the greatest industrial cities of the world.

\section{References}

Cameroon Tribune (2009). 13 May 2009, p.16.

Djilo, T. C. A. (2008). Determinants Geographiques et Spatialisation des Maladies D’origine Hydriques dans une Ville Balneaire Africaine: Le Cas de Kribi dans le Sud Cameroun. Maitrise Dissertation, Douala: Université of Douala.

Fogwe, Z. N. (2008). The Cameroonian City Counter Flood Response Strategies of the 21st Century. Journal of Applied Social Sciences, 7, 124-141

Médecins Sans Frontières, Schmitz, J., \& Mendoza, J. (1993). Enquête sur le Maladies diarrhéiques. Douala: Centre de Santé intègre de Soboum-Zone Nylon Douala.

Ministry of Territorial Administration and Decentralisation (2008). Risk Prevention Plans (RPP) of Some Zones around Mount Cameroon. Yaounde: Department of Civil Protection and French Cooperation Service.

MINPAT (2000). Study of the Optimisation of the Socio-economic Impacts Resulting from the Creation of a Shipyard at Limbe for a Sustainable Development, Greenhills Consults, Yaounde.

Munyele, B. J. E. (2008). The Geo-Environmental Effects of Petroleum Refining on a Coastal Ecosystem: Case of SONARA, Limbe, SW Cameroon, Maitrise Memoir, Yaounde I University.

National Institute of Statistics (2002). Enquête sur le cadre de vies des populations de Yaoundé et de Douala en 2002, Vol. IV B: Résultats pour l'arrondissement de Douala III. Yaounde: MINPAT

Ngandjui, J. (1986). La Croissance d’une Ville de Port Secondaire du Cameroun: L’Exemple de kribi. Maitrise Dissertation, Yaoundé: Université of Yaounde, 15.

Roumy, M. (1983). Principes d'une planification urbaine intégrée. L'expérience de développement, auto centre de la zone Nylon Douala-Camerooun. Paris: EHESS Thèses de Doctorat.

Tchawa et al. (2004). Plan d'Amenagement et de Gestion dela Bande Cotiere Kribi-Campo dans la Perspective d'un Tourisme Durable.

Tiafack, O. (2013). Contours of Urban Disorder and Health Hazards along Messa Mountains (NW of Yaounde) and Nylons of Douala, Cameroon. In Urbanisation, Environnement et Enjeux Sanitaires En Afrique, Germany.

Tiafack, O. et al. (2009). Uncontrolled Draining of Rainwater and Health Consequences in Yaounde, Cameroon. Acta Universitaria, 19, Dirección de apoyol a la investigación y al posgrado, Spain, 20-30.

Wambo, E. M. N. (2008). Hygiène du cadre de vie et action communautaire a Nylon-Douala. Visages et Defis des Principales Villes Camerounaises, Montreal: Montreal University.

Zogning, A. (1994). Limbe: Une Ville de piedmont d'un Volcan Actif en Milieu Tropical Humide. Revue de Géographie. Alpine no Spécial sur Croissance urbaine et Risque Naturels, Principalement dans les Pays en Développement No 4 Tome LXXXII, 71-86. 
Scientific Research Publishing (SCIRP) is one of the largest Open Access journal publishers. It is currently publishing more than 200 open access, online, peer-reviewed journals covering a wide range of academic disciplines. SCIRP serves the worldwide academic communities and contributes to the progress and application of science with its publication.

Other selected journals from SCIRP are listed as below. Submit your manuscript to us via either submit@scirp.org or Online Submission Portal.
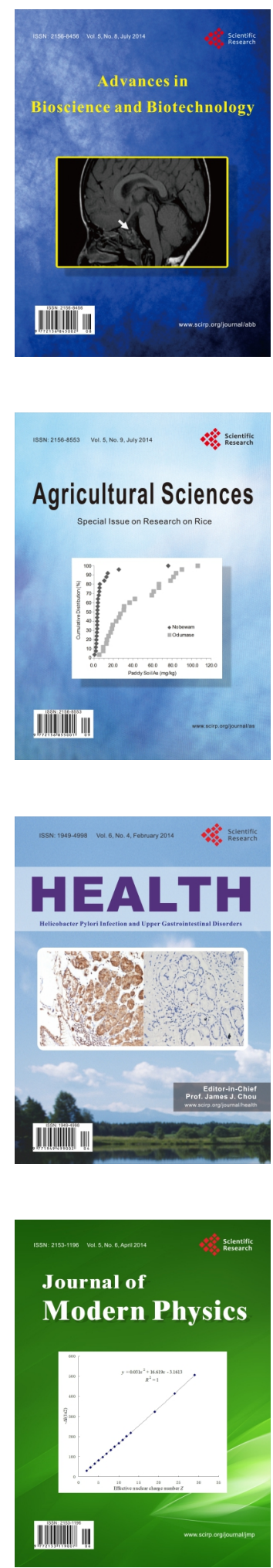
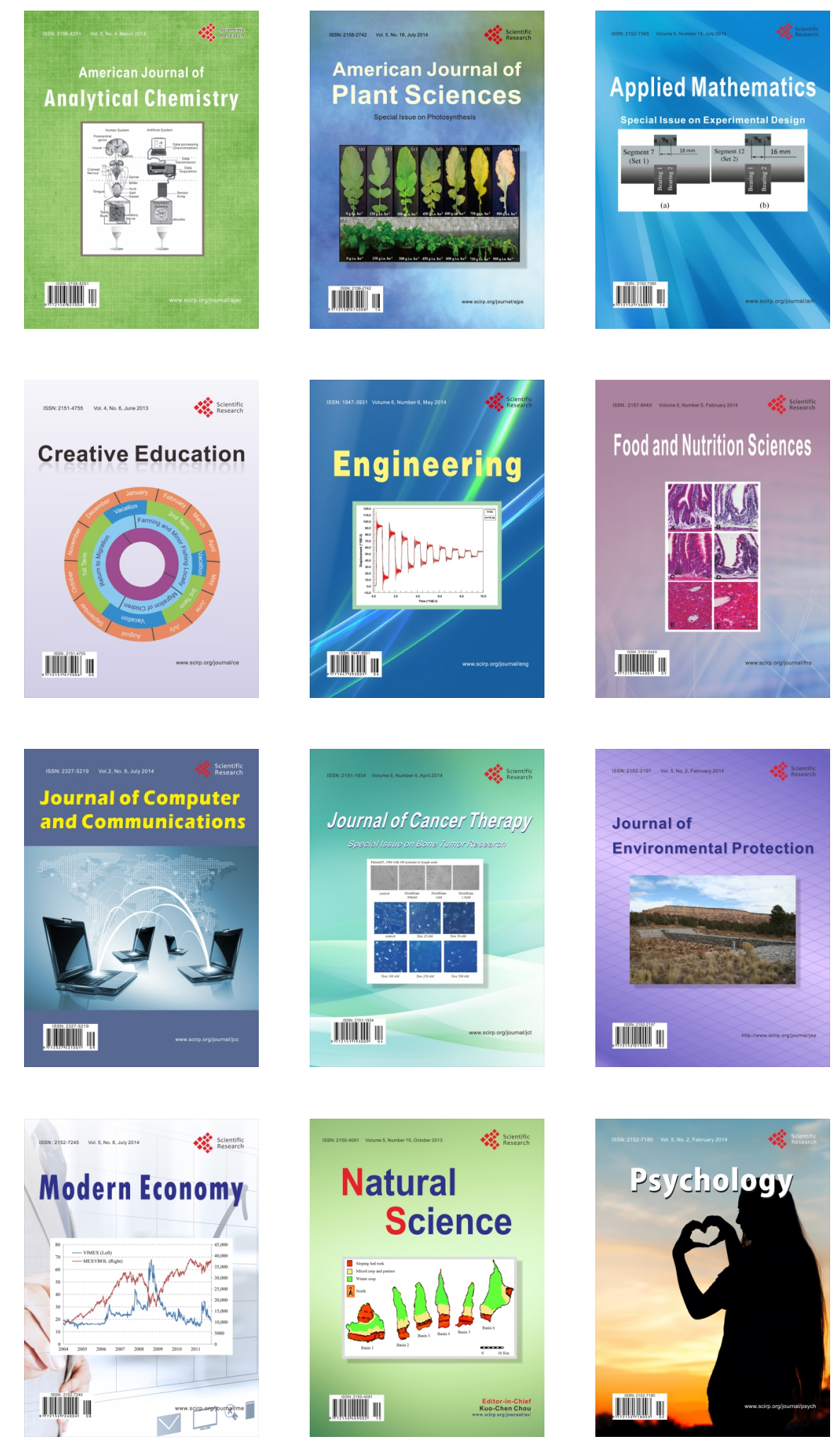